\title{
CORRIGENDUM
}

\section{CALENDAR AGE OF THE BAIGETOBE KURGAN FROM THE IRON AGE SAKA CEMETERY IN SHILIKTY VALLEY, KAZAKHSTAN - CORRIGENDUM}

Irina P Panyushkina • Igor Y Slyusarenko • Renato Sala • Jean-Marc Deom• Abdesh T Toleubayev

In the original publication of "Calendar Age of the Baigetobe Kurgan from the Iron Age Saka Cemetery in Shilikty Valley, Kazakhstan," the grant attributed to co-author Slyusarenko was incorrectly provided. The correct grant information should be RSCF \#14-50-00036.

The authors regret this error.

\section{REFERENCE}

Panyushkina IP, Slyusarenko IY, Sala R, Deom J-M, Toleubayev AT. 2016. Calendar Age of the Baigetobe Kurgan from the Iron Age Saka Cemetery in Shilikty Valley, Kazakhstan. Radiocarbon 58(1):157-67 doi: 10.1017/ RDC.2015.15. 